\title{
The complex role of a salesperson in an appliance sales context
}

\author{
Alet C Erasmus and Alida J Gothan
}

\begin{abstract}
OPSOMMING
Die groot getal navorsingspublikasies oor kliëntediens gedurende die afgelope dekade dui op die belangrikheid van die onderwerp. Studies het onder meer getoon dat verbruikersfasilitering ' $n$ belangrike bydrae ten opsigte van uiteindelike verbruikerstevredenheid en veral ten opsigte van verbruikers se geneigdheid tot winkel lojaliteit, maak. Die bydrae van verkoopspersoneel raak selfs belangriker ten opsigte van duursame, komplekse produkte. Hier gebeur dit dikwels dat die verskeidenheid produkte op die mark verbruikers so oorweldig dat hulle nie oor die kennis en ondervinding beskik om sonder hulp ingeligte, verantwoordelike produkbesluite te neem nie. Ongelukkig rapporteer navorsers verder dat die kollektiewe rol van ' $n$ verkoopspersoon in die kleinhandel, baie kompleks en veeleisend is. Die vraag is dus of ' $n$ verkoopspersoon verbruikersfasilitering - wat net een aspek van die kollektiewe verkoopsrol verteenwoordig - as ' $n$ prioriteit beskou en of ander rolvereistes moontlik voorkeur geniet omdat dit as meer lonend beskou word. Terwyl verbruikers dus onder die indruk verkeer dat hulle op verkoopspersoneel kan staatmaak en dat verkoopspersoneel vertrou kan word om hulle te fasiliteer om ingeligte verbruikersbesluite te maak, mag konflikterende en verwarrende rolverwagtinge optimale ondersteuning aan verbruikers belemmer.
\end{abstract}

Hierdie navorsing het ten doel gehad om die komplekse rol van ' $n$ verkoopspersoon soos wat dit kollektief tydens daaglikse roetine realiseer, te beskryf. Uiteindelike was dit van belang om te beskryf hoe die rol as verbruikersfasiliteerder figureer tydens ' $n$ transaksie. Die invloed van belemmerende faktore soos verwarring ten opsigte van rolverwagtinge en rol stress is in aanmerking geneem. ' $n$ Interpretivistiese benadering is gevolg om ' $n$ interne perspektief van ' $n$ verkoopspersoon se persepsie van sy rol in die kleinhandel te verkry deur middel van ' $n$ diepte studie van 'n klein steekproef. Kwalitatiewe data insamelingstegnieke is gebruik.

Daar is gevind dat ' $n$ verkoopspersoon in die algemeen 'n hoë premie plaas op sy ondersteunende rol as verbruikersfasiliteerder en dat dit die rol is wat die meesste geniet word omdat dit tot 'n gevoel van eie waarde bydra. Ongelukkig word hierdie rol dikwels nagelaat ten gunste daarvan dat verkope bevorder moet word (klem op die rol as werknemer) om verkoopsteikens te bereik waardeur tersefdertyd groter kommissies verdien kan word. Laasgenoemde verhoog spanning tussen kollegas wat kompeteer om kliënte te wen eerder as om mekaar by te staan en te ondersteun. Kommissie gebaseerde vergoeding blyk die belangrikste oorsaak van verwarring en spanning onder vekoopspersoneel te wees wat interaksie tussen kollegas belemmer en verkoopspersoneel se optrede teenoor verbruikers negatief beïnvloed.

\section{- Dr Alet C Erasmus \\ Department of Consumer Science University of Pretoria}

\section{- Ms AJ Gothan}

Department of Consumer Science University of Pretoria 


\section{INTRODUCTION AND MOTIVATION FOR THE STUDY}

Extant research on service quality in retail specifies salespeople as important contributors to optimal service delivery through which a retailer could be distinguished as superior and could gain a competitive edge (Clopton et al, 2001; Evans et al, 2000; Goff et al, 1997; Grewal \& Sharma, 1991; Jacobs et al, 2000; Reynolds \& Beatty, 1999; Sharma \& Levy, 1995). Not surprising then, is the fact that many retailers nowadays often refer to their salespeople as either a sales assistants or sales executives to acknowledge their potential contribution in the work place.

Apart from the basic facilitation of transactions, salespeople are expected to provide expert product knowledge and to cope with a complexity of administrative duties, to provide emotional assistance to potential customers and to excel in their communication and social skills to win over and retain customers for the sake of better business and their commission based remuneration. The collective role of a salesperson in the retail environment is a multiple one that eventually incorporates the roles of consumer facilitator; employee; colleague as well as that of an individual with personal expectations (Tyson \& York, 1996:3, 10). Role stress occurs when an individual finds it difficult to interpret and coordinate these roles simultaneously (Churchill et al, 1990:334, 335; Wetzels et al, 2000). Research indicates that the problem may be aggravated by consumers who have become more demanding in recent years and who, instead of buying products, demand benefits and best value for money (Samson \& Little, 1993:390). Research findings further indicate that the money spent on product development and promotion is often negated by the poor performance of salespeople in store (Clopton et al, 2001).

Despite an abundance of research on the salesperson per se, the role of a salesperson apparently still seems ill structured (Evans et al, 2000). Attempts to understand and improve salespeople's performance in retail have generated a considerable amount of research (Churchill et al, 1990:334, 335; Plank \& Reid, 1994). Plank and Reid (1994) contributed to the well-known Churchill, Walker and Ford model of sales performance (1979) through the addition of influencing variables. They also made explicit the importance of the situational context. The model nevertheless still proposes an "outsider view" of a salesperson's performance in the work place. Little evidence could be found regarding sales behaviour in a situational context. Considering the impact of a salesperson on the eventual transaction, the customer and the retailer, the role of the sales person deserves to be better defined and understood.

\section{PROBLEM STATEMENT}

Any study that exclusively focuses on the role of the salesperson as consumer facilitator without taking into consideration the collective and interactive effect ex- erted by the other roles and related obligations, does not disclose the reality of what is experienced on a daily basis. Based on what a salesperson has to cope with during daily routine, this research was concerned with how the various roles of a salesperson are integrated and eventually culminate in the working environment as a collective role, acknowledging the effect that the employer, customers, colleagues and personal considerations might have on the eventual interpretation of the role.

\section{RESEARCH OBJECTIVES}

Foremost was the intention to reveal a salesperson's role as consumer facilitator as it culminates as an element of a multiple, interactive role to indicate the extent of support that could be expected by consumers during a sales encounter. It was expected that the role of a salesperson as consumer facilitator, however important it might be regarded by salespeople during their interaction with clients, may be diminished during daily routine in favour of the other roles and related obligations because they exert more pressure or may be considered more rewarding.

This necessitated a description of a salesperson's interpretation of his/her role in the capacity of:

- employee

- consumer facilitator or advisor

- colleague

- as an individual (person).

in terms of how these roles are interpreted/understood individually, and how these roles eventually culminate towards the collective role in the work place.

\section{CONCEPTUAL BACKGOUND}

\section{The role expectations of a salesperson}

The role of a salesperson consists of various role expectations that are transformed in the work place in terms of a perceived role that determines eventual performance (Plank \& Reid, 1994). The job description of a salesperson that sets the role parameters is not necessarily communicated in a formal way and it often manifests as the interpretation of the expectations and demands of influential others such as the management, customers and colleagues (Churchill et al, 1990:335-338). Different role expectations during the daily routine require of a salesperson to continually adjust to cope with role stress (Spears \& Gregoire, 2003:9). Role conflict occurs periodically because of over emphasis of one role dimension. An employee might for example feel obliged to clinch a deal to meet sales targets and consequently intentionally neglect the role of consumer facilitator that requires the sharing of product information that might encumber the transaction (Cuff \& Payne, 1981; Kahn et al, 1964 in Wetzels et al, 2000). This could result in role stress - a composite construct of the role stressors of role conflict and role ambiguity - because of the contradiction of a personal need to provide expert advice to customers. Role stress is detrimental to job satisfaction. 
The various roles of a salesperson should thus be acknowledged in terms of their individual as well as their collective effect on sales behaviour in situational context (Spears \& Gregoire, 2003:7-9). Behaviour with positive outcomes is generally repeated. If management for example continually applauds increased sales, a salesperson would probably enhance and even favour the sales role and be convinced to walk the extra mile to secure as many transactions possible. This would negatively impact on the role as consumer facilitator and is disadvantageous in terms of the ideal of informed consumer decision-making (Churchill et al, 1990:334-338; Spears \& Gregoire, 2003:9).

\section{The multiple roles of a salesperson}

As consumer facilitator Service quality is defined by the customer, but created by employees: it is often the human factor that ultimately defines service quality. Goff et al (1997) found that salespeople's behaviour with respect to selling orientation-customer orientation (SOCO) significantly influences customers' satisfaction with the salesperson, dealer, product as well as the manufacturers and it has been found that consumers frequently recall and complain about bad experiences with salespeople (Morris, 2002:28). "Relationship retailing" with an emphasis on maintaining good relationships with customers is thus recommended (Clopton et al, 2001). Saxby (2003:4) is even more explicit in his summation that the very existence of many retailers depends on their sales personnel who actually represent their employers (retailers) in their interaction with consumers. When Rabinovitz (1997 in Naylor \& Frank, 2000) describes the role of the salesperson, he briefly concludes that they " should make the lives of their customers easier". In a modern, competitive market place, where time pressure often limits proper product evaluation, Rabinovitz's view may be considered the ideal - especially for complex consumer decisions such as major household appliances where the choice of products and technology that are offered, often overpowers the consumer (Chernev 2003; Huffman \& Kahn, 1998). When consumers feel uneasy about shopping for whatever reason, they literally become dependant on competent salespeople to guide them through the buying process (Grewal \& Sharma, 1991; Kotler, 1994:35, 172, 173 ). It has been reported that customers often deliberately choose certain retail stores and salespeople because they appear to be empathetic, supportive and trustworthy (Beatty et al, 1996; Campbell \& Kirmani, 2000; Davies, 2001; Du Plessis et al, 1999; Weinstein, 2001). It has been reported that a salesperson often even acts as the surrogate shopper during the final stages of decision-making (Beatty et al, 1996; Reynolds \& Beatty, 1999).

As employee Every salesperson has time consuming task related administrative duties as well as people orientated responsibilities that include customer service. Salespeople represent the "front line contact" with a store. They generally act on behalf of the management of a store and even determine the image of a retail store (Bettencourt \& Brown, 1997; Jobber,
1998; Wetzels et al, 2001). Clopton et al (2001) acknowledge this responsibility when they reported that it is considerably more costly to replace a lost client than to keep an existing one.

As a colleague Neglect of a salesperson's role as colleague is conducive to friction and tension that might impact negatively on the business in various forms. It might result in a high staff turnover, an overall negative morale, envy and even hostility (Pettijohn et al, 2000). Irrespective of the type of organization, it has been found that interdependent, supportive colleagues characterize a united work force. Teamwork is thus encouraged to maximise work performance. Ideally speaking, an experienced salesperson should serve as role model for new and less successful employees (shadowing) to encourage strong positive norms and a healthy supportive culture within the company (Beatty et al, 1996; Marino, 2001). Recognition from superiors through incentives such as salary increases and promotion, contribute to job satisfaction, which is conducive to work performance (Goff et al, 1997).

Personal needs and expectations According to Beatty et al (1996), self-motivated salespeople are generally more successful in their jobs. They are also more inclined to provide augmented customer service, which means that personal needs and expectations should be attended to to enhance the performance and consequent job satisfaction of employees. It further enables an ability to address and adjust to conflicting situations and to juggle a multitude of roles and responsibilities.

\section{An interpretation of the multiple roles of a sales- person within a systems perspective}

In this study, the focus was on role perception as an output of a system where the salesperson's roles as employer, consumer facilitator, colleague and as individual (having personal expectations) are transformed/ interpreted as a collective role. Within a systems approach (Figure 1), specific inputs (different role expectations) are transformed to culminate in a perceived role (output) that eventually determines the behaviour of the salesperson (Cuff \& Payne, 1981:23; Haralambos, 1983:9, 521-523). This particular system should be considered as an open system because a salesperson does not work in isolation: interaction with colleagues, competition with other retailers, family responsibilities and pressure exerted by employers in terms of job performance all contribute to an individual's collective interpretation of his role (Whitchurch \& Constantine, 1993:333). The environment in which the salesperson operates is external to the system, but will, in some way, be in direct or indirect transaction with it. Because human systems are embedded in and transact strongly with their environment, it is not possible to gain a full understanding of human systems apart from the context in which they are found (Whitchurch \& Constantine, 1993:333).

A systems approach focuses on the whole process (in this instance role perception as a culmination of differ- 


\section{CONTROL}

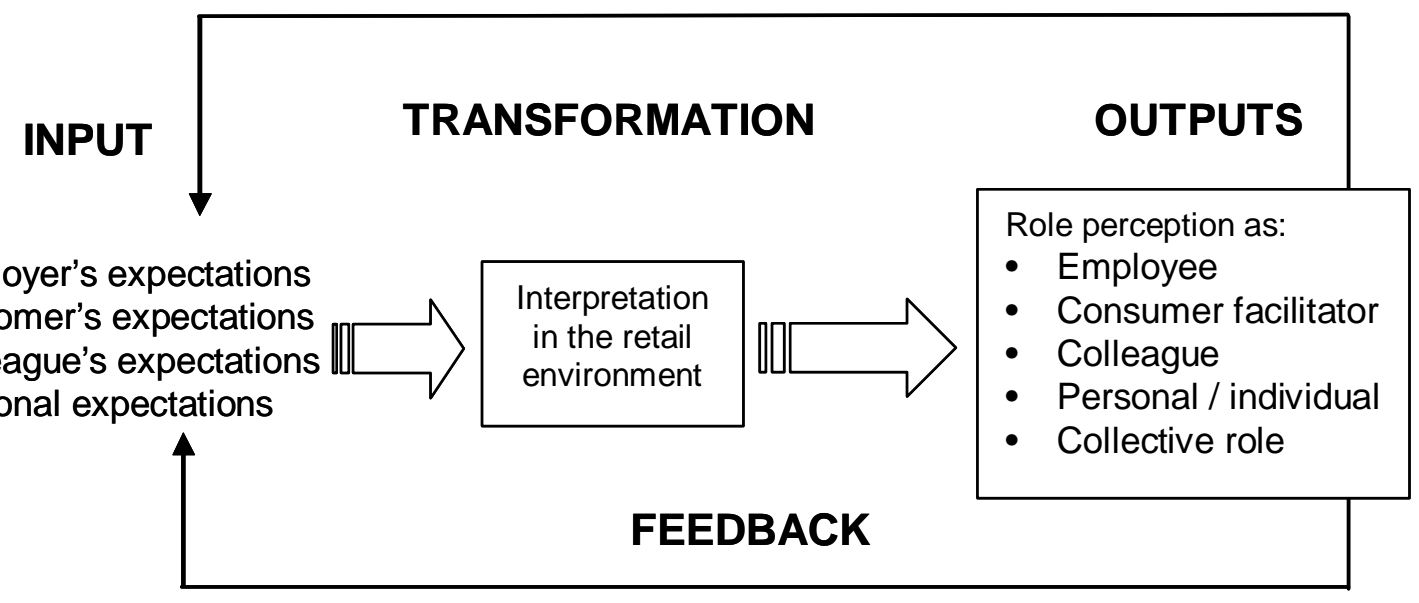

FIGURE 1:

CONCEPTUAL FRAMEWORK DEPICTING THE MULTIPLE ROLES OF A SALESPERSON WITHIN A SYSTEMS PERSPECTIVE

ent roles), and how various elements of the system (specific individual role perceptions) contribute to the system. These are studied with reference to their interactive contribution to the whole system (Gestalt theory), rather than as isolated units. A salesperson's perception of his role will eventually culminate as the end product of the interactive variables (Spears \& Gregoire, 2004: 7; Whitchurch \& Constantine, 1993:328). It will consequently affect the salesperson's performance in the workplace where constant action between the internal and external environments of the system continually adapts (acts and reacts) to maintain equilibrium. The interdependence between the parts (different role perceptions) means different role perceptions affect one another as interactive parts in the system to the extent that change in one part will lead to change in the other parts (e.g. if an employer's demands affect a salesperson's role as employee, it will inevitably also impact on a salesperson's role as consumer facilitator). In the situation of the salesperson, change will be monitored by the particular structure of the system, in order to maintain equilibrium or balance in the system among the various parts. The salesperson might for example try to satisfy the employer as well as the customer, but in doing so, he might neglect personal needs and expectations (role of self fulfillment). The objectives of the organization can best be achieved through an understanding of a salesperson's role perception to facilitate the effective use of human resources, along with its financial and physical assets (Megginson, 1977:1).

Areas of integration between the subsystems, e.g. between the salesperson and the employer and/or the customer and/or colleagues and/or personal expectations represent the interface of the integrated system. Overlap of these areas may be characterized by tension and friction: for example a salesperson struggles to balance and cope with the demands from various angles (Megginson, 1977:12; Spears \& Gregoire, 2004:8). A salesperson's ability to integrate and manage these variables will determine his role perception.
Control elements and the general feedback into the system affect the flow of the system. The control elements may e.g. include the goals and objectives of the organization (employer). Information is traced from one point in the system, through one or more other parts of the system or its environment, and back to the point of origin where the information is ultimately fed back into the system as positive or negative feedback (Whitchurch \& Constantine, 1993:334). Positive feedback may eventually be accepted/ preferred (e.g. a salesperson repeats behaviour to attend to an unhappy customer). Feedback is essential for the continued effectiveness of the system (e.g. if a customer returns with a positive attitude, and if an employer expresses his satisfaction, the role perception of the salesperson in a specific capacity, will be influenced positively (Spears \& Gregoire, 2004:8). A salesperson's role in the working environment could culminate in various ways (equifinality) (Whitchurch \& Constantine, 1993:334): he could for example interpret his role as consumer facilitator as the most important, or he could interpret it as a less significant, integral part of all the other roles.

In Consumer Science, the concern would be to understand a salesperson's perception of his role as consumer facilitator in terms of the interactive effect of other roles that have to be attended to. That would provide an understanding of the kind and level of support that could be expected during consumers' purchasing of complex durable goods, which may involve a considerable amount of risk. On the other hand, an understanding of a salesperson's perception of his role in the working environment might also provide valuable insight for employers in terms of a salesperson's contribution towards the business.

\section{RESEARCH APPROACH}




\section{Method of enquiry}

The research problem necessitated an interpretivistic, ideographic research approach to obtain an insider perspective of a salesperson's role behaviour. A small sample was used to allow for repetitive contact sessions with participants and a more intensive investigation. Qualitative techniques that allowed for spontaneous, uninhibited responses from participants were implemented (Babbie \& Mouton, 2001: 272, 281; Hammersley \& Atkinson, 1995: 24, 25).

\section{Sample}

The cooperation of various retailers in the Pretoria Centurion was negotiated as required: three major department stores that stock a relatively large variety of appliances as well as a specialist home appliance retailer and one smaller more exclusive appliance outlet were eventually included. These were all within a $25 \mathrm{~km}$ radius but were at least $5 \mathrm{~km}$ apart. With the approval of the management of the stores, only one salesperson in the home appliance department from each store was recruited for participation. Pre conditions for participation were their willingness to cooperate, availability at the time of the appointment and that they had to have been involved in sales of appliances at the time of the study, with a minimum of two years of sales experience. Participants were selected irrespective of age or gender, but no supervisors were included. Interviewing with potential participants was terminated when no new information came to the fore during the combination of data collection procedures. To create an atmosphere of trust, confidentiality was promised. Five in depth interviews were eventually done.

\section{Data collection}

Three stages of data collection secured the data that was required. Contact was made in the work place during working hours with the permission of the management and supervisors of retailers to encourage participation and to limit any form of hesitation about the information that was shared.

Individual interviews These were used as a first stage to set the scene for more relaxed relationships with participants, which is vital for uninhibited responses. Interviews were halted at the point when interviews with new participants only repeated information that was already noted and nothing new came to the fore. Five interviews were eventually conducted. Interviews were unstructured, flexible and nondirective to encourage spontaneous conversations (Kvale, 1996:103). Certain pre-mediated questions were however relied on to guide discussions within the objectives of the study (Mouton, 1996: 149-157). These were:

- How would you describe your contribution and responsibilities as a salesperson in this department in the store to somebody who might be interested in a job? In other words what are expected of you as a salesperson on a daily basis?

- Do you have a job description? Are your responsi- bilities clear and easily identifiable? Please explain.

- Do you consider certain of your responsibilities/ activities more important and preferable in terms of job satisfaction? Explain.

- As a salesperson, do you regard certain responsibilities more worthwhile? Explain.

- Would you like to change some of your responsibilities as a salesperson in this department to increase job satisfaction?

- What gives you job satisfaction?

- Why have you chosen this particular job?

- How does your relationship with your employer/ colleagues/customers contribute to job satisfaction?

Conversations were unstructured in terms of specific content, order of discussion and how much to contribute on any aspect that came to mind. Note was taken of non-verbal reactions of participants to illuminate the data (for example when participants were reluctant to elaborate on certain issues, the order in which they discussed certain topics spontaneously as well as their enthusiasm or lack thereof) (Babbie \& Mouton, 2001:291). Interviews were tape recorded with the permission of participants and were later transcribed. Debriefing was done immediately after every interview to reflect on the truthfulness of data.

Projective technique The same participants were asked to participate in a written exercise during a follow-up meeting after two weeks. The intention with this technique was to generalize participants' opinions and experiences and to validate the data that was obtained through personal interviews of which the content was more personal in nature. Participants were required to write down parameters for a "Salesperson of the year"- assuming three different scenarios. They were first required to react in the hypothetical capacity as a store manager. Next, they had to repeat the exercise as an experienced salesperson and lastly in the capacity as a customer who had recently purchased household appliances. This provided opportunity for triangulation and served as a tool to enter into the private worlds of participants to uncover their inner perspectives in a non-threatening manner (Donoghue, 2000).

Follow up discussions Upon completion of the second data collection session, every participant was asked to motivate the suggested parameters during individual interviews. These were once again taperecorded with their permission to be transcribed and analyzed for the purpose of triangulation.

\section{Data analysis}

An iterative process was used to analyze transcriptions of the interviews. A process referred to as memoing was used and the procedure suggested by Perreault and Leigh (1989) was followed to code the data. The researchers independently coded the data and then compared and evaluated their interprettions. Problems were discussed and corrected where necessary and re evaluated to improve coding accuracy and inter coder reliability. 
The study objectives and role theory provided the core categories according to which statements were clustered: open coding as well as axial coding were used to allow for non-expected comments and influences (Babbie \& Mouton, 2001:500). Statements were clustered as either task orientated or relationship orientated because these represent the two dimensions of one's role in a specific context (Churchill et al, 1990: 335; Jarvis: 1). Subcategories were formed to differentiate consensus statements or individual statements (those not necessarily affirmed by all). Categories were formed in terms of role perceptions and in terms of causal factors and coping strategies because these became apparent during all of the interviews. Axial coding was used to reassemble data (Babbie \& Mouton, 2001:500). Truthfulness of the researchers' interpretations was later reviewed using Atlas.TiTM vs 4.1 (a qualitative academic computer data analysis system) whereby qualitative data is scrutinised, coded and categorised for interpretation.

The above process was repeated for data generated through the projective technique to identify mutual concepts and to ensure authenticity of data. Data generated using the different techniques was then integrated to group information that was reciprocal and mutually reinforcing.

\section{Trustworthiness}

Several attempts were made to reduce error. Alternative methods of data collection were used to enable different constructions of reality by the same participants. This allowed for critical evaluation and cross checking of data (Babbie \& Mouton, 2001:277; Wallendorf \& Belk, 1989). Care was taken with the recruitment of participants: they were intentionally chosen from stores and different locations to prevent possible interaction of participants and to capture experiences from a broader view instead of one retailer only. It was further reasoned that in store interviews would permit explanatory evidence and would limit reluctance to participate which could very well have been the case if contact sessions were held after their already long working hours. Because truthful data depends on the voluntary, willing and unrestrained responses of participants, only individuals with a minimum of two years' prior experience were included. Interviews ceased when no new information came to the fore. Data was transcribed and analyzed immediately after every interview to guide subsequent interviews. Member checking, i.e. a reflection on transcriptions by the participants for affirmation, was done to avoid misinterpretation by researchers. Member checking was also done on completion of the projective techniques.

\section{INTERPRETATION OF DATA}

\section{Interpretation of data gathered through interviews}

The following reflect examples of statements (in the words of the participants) as they were recorded during interviews. Because limited space prevents full disclosure of data, only typical comments are given organized as they were clustered in accordance with the research objectives and subsequent categories of information and concepts that came to the fore. Each role was eventually described in terms of task orientated and relationship-orientated responsibilities.

Job description Confirming Churchill and co workers' report (1990:335), interviews revealed that salespeople seldom (if ever) receive formal job descriptions. Instead of reacting to it negatively, participants perceived this practice as a form of trust. Comments included:

- A salesperson seldom gets a job description. Management relies on our experience and insight to do our jobs.

- I have been in sales since 1995. I have never had a formal job description.

A salesperson's role as employee Without exception, all participants identified the same categories of responsibilities when describing the role of the employee. These were differentiated and are outlined in Figure 2.

Task oriented administrative responsibilities Statements relating to organizational /administrative duties in a task orientated context were mutual. These included pricing of stock, handling of queries, liaison with suppliers and general attendance to the department.

Statements included:

- We clean our department every morning

- We change the prices according to a print out that we receive once per week.

- It is my duty to see that every appliance has a price tag.

- If needed, I get technical information for the customers from the suppliers.

Task oriented responsibilities as product specialist Statements relating to the task orientated duty of acting as a product specialist revealed noticeable differences in how salespeople are supposed to obtain their expertise. Statements included:

- Product knowledge is very important. You must know your product. The suppliers train us, especially on new products

- Nobody trains you: you must teach yourself because you have to know how everything works

- I read the manuals of the various appliances to refresh my memory on how to operate them

- One learns all the time.

- Product knowledge is very important. If you are unable to answer a question, it may cost you the sale.

Task oriented sales responsibilities Statements relating to sales as a task-orientated duty revealed a prominent responsibility to continually pursue sales targets. This was considered fundamental for the business as well as for their commission-based remuneration. The importance of sales was evident through statements such as:

- One stands all day long and must be available at 


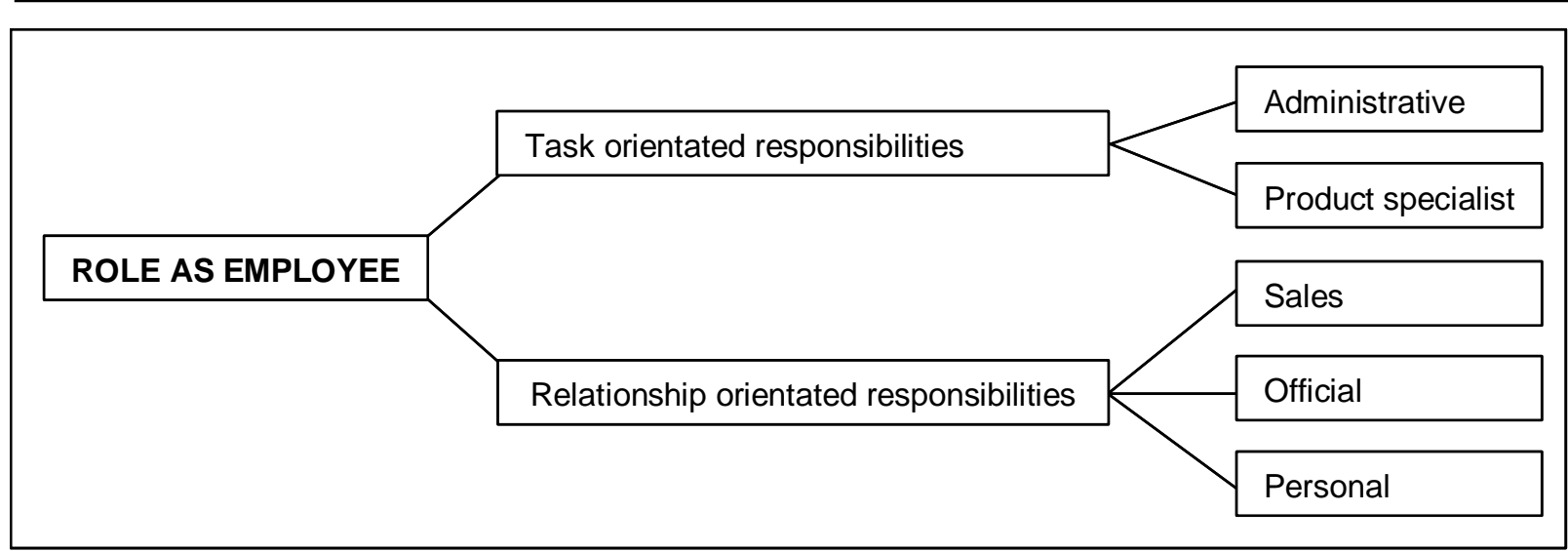

FIGURE 2: CATEGORIZATION OF A SALESPERSON'S ROLE RELATED RESPONSIBILITES

all times not to loose customers and sales. One should not loose sales.

- We have to sell. We all are salespeople: there is no hierarchy or ranks based on your work.

- We create our own income through commission.

- It is important to sell something - that is good for the company too.

Relationship oriented official responsibilities Statements referring to official responsibilities in a relationship-orientated context seemed consensual. A salesperson apparently acknowledges his/her responsibility to represent management and to contribute to the image of the business through excellent customer service. This was apparently perceived as a form of trust although they also experienced some disregard. Negative comments included that managers depended on salespeople to represent them during daily routine but that they were considered subordinates when personal issues were involved. This seemed ambiguous in terms of a salesperson's personal worth. Statements included:

- They trust us to act on their behalf when it comes to customer care.

- A salesperson has all the responsibilities but management does not care about us.

- In a sense they trust us to do the work but a salesperson is not regarded as a valuable asset to the company. There are no rewards like a rank structure.

- It is very frustrating, but it is no use getting angry with the management because they are superior.

- They accuse the salespeople of not having respect for the management.

Relationship oriented personal responsibilities Conflict of opinion may be attributed to different management systems. On the one hand, some stated that:

- Mutual understanding creates a good relationship with the management.

- It's wonderful that they trust me to help to talk about our salaries.

- Management listens, and they do something to help.

Contradictory statements that may indicate role conflict, included:

- Sometimes it is difficult to get the management to assist.
- You have to fight your own battles - they do not understand your problems.

A salesperson's role as consumer facilitator The role as consumer facilitator was discussed spontaneously, with enthusiasm and seemed to contribute to a feeling of self worth.

Consumer facilitation in a task-oriented context These statements referred to their expertise that enabled an informative, supportive contribution during their interaction with customers. Participants were clear what was expected in this capacity although the fact that they had to acquire the expertise on their own seemed ambiguous. The following thoughts were shared:

- Basically you must tell the customers everything.

- I help the customers to choose. I give them information and advice about the appliances.

- I sell solutions. People come in here with problems. They ask the questions and you answer.

- Sometimes customers ask technical questions. If I cannot help them I phone the suppliers.

Role conflict surfaced where consumer facilitation had to be compromised to secure a deal for the sake of increased sales and better commissions. It became clear that the economic principles are generally considered first priority. The following were inter alia said:

- My job is to change the customer's mind. I must ask him what he wants, but I have to sell something that is also good for the company.

- Some customers are willing to pay more if they think it is better quality. It is my duty to convince them that paying more is better.

Consumer facilitation in a relationship-oriented context Statements referring to a relationship orientated context generally related to forming and maintaining good relationships with customers based on their approval and trust. Effort was even made to retain difficult customers. The following came to the fore:

- I must take care of the customer. If the customer has a problem, we will sort it out.

- The customer is very important. 
- I have a good relationship with my customers. I talk to them as if they are my friends.

- If a client trusts me, I will sell something to him.

- My customers believe me and trust me.

- Sometimes we have difficult customers. I try to help them, but you have to control yourself.

Relationship orientated behaviour, for example efforts to maintain customers, were occasionally in conflict with task related responsibilities. These roles often seemed incompatible. Statements included:

- It causes pressure for me if the suppliers let me down and I cannot please the customer.

- Unfortunately not many people listen to us, because they do not trust us. They know that we earn commissions.

- It is very difficult to keep the customer and the manager happy.

A salesperson's role as colleague Participants had to be prompted to discuss their interactive roles as colleague. Even then, discussions were brief and cautious and evolved around conflict: apparently commission-based remuneration was a main cause of lack of support and friction among colleagues. This is inconsistent with what is suggested by Marino (2001) in terms of maintaining an integrated work force for the sake of a positive store image.

A salesperson's role as colleague in a taskoriented context Statements in a task related context were limited and revealed conflict of interest. Positive statements included:

- We operate as a team.

- All salespeople are obliged to obey the same rules.

- A sale is like a sport - you must act with responsibility and with dignity. Nobody will admire you when you are aggressive or when you cheat.

Contrasting views included:

- We are not a team, we compete for commission.

- Colleagues sometimes steal your customers.

A salesperson's role as colleague in a relationship-orientated context Statements in a relationship orientated context revealed tension. The ambiguity of having to support colleagues while striving to increase commissions was evident although it seemed incidental and may be resolved. Statements included:

- Competition among colleagues with sales and commission can be motivating.

- There is no tension among us, we assist one another.

Contradictory statements that suggest conflict were inter alia:

- My colleagues are absolutely careless, their irresponsibility creates tension between us.

- We are working on commission and that leads to tension. We fight over customers.

A salesperson's role as individual with personal expectations Conflict within individuals in terms of personal progress and well being mainly evolved around working conditions and salaries. Physical and psychological demands of their jobs seemed incongruent with their earnings.

A salesperson's role as individual with personal expectations in a task oriented context

Statements mostly referred to their expertise, which necessitated extensive product knowledge:

- You have to know everything.

- It is your own responsibility to get the latest product information.

- Consumers depend on you to know everything.

Tension was detected in statements such as:

- You are always tired. We work seven days per week. It is very tiring.

- So much work for so little money!

A salesperson's role as individual with personal expectations in a relationship oriented context

Statements in a relationship orientated context evolved around their personal significance to the businesses and the formation of lasting relationships with customers. Role conflict occurred when trade offs had to be made to increase sales, especially when their actions were to the disadvantage of customers:

- I like my job - I enjoy talking to people. It makes me feel good to help the customers.

- I have a passion for customer service. I think that is the main thing.

- It is definitely worthwhile. I do not even want to sit down, because if you sit you loose sales.

Statements revealing tension included:

- I must change the customer's mind. I must sell him something that is good for him, but that will be good for the store too.

- I hate to disappoint customers, but my job comes first.

\section{Interpretation of data gathered through projective techniques}

The data that was collected through the projective technique provided an opportunity to avoid error in interpretation of the data collected through individual interviews. Although the nature of the projective technique required a description of the ideal situation from different viewpoints, it was anticipated that participants would refer to outstanding personal experiences and that they would include the most significant concepts. Limited space once again prevents full disclosure of data. For the purpose of attending to the objectives of the study, only statements that revealed new or alternative insights to those that were revealed in the interviews, are listed.

The ideal salesperson from manager's point of view The ideal salesperson was described in terms of a task oriented context and a relationship oriented context.

The role in a task oriented context There seemed to be clarity and general agreement on the administra- 
tive role of a salesperson as well as the role as product specialist. Interestingly it was even specified that it is a salesperson's own responsibility to acquire the product related expertise although this was mentioned as being unfair during interviews. Content analysis revealed the same denominators (tasks related to pricing, displays, etc.) as those indicated during the interviews, which confirms participants' certainty about this specific role. Only one additional criterion was mentioned and this referred to the appearance of the salesperson as an important contributor to the image of the business, namely: "The salesperson must compliment the image of the company by being neatly dressed in the company uniform".

\section{The role in a relationship orientated context}

Statements with respect to the relationship orientation of a top performing salesperson supported the content of the interviews. Commitment towards task performance was prominent although participants accentuated the importance of customer service when they had the opportunity to act "on behalf of management". The projective technique thus provided the opportunity for participants to express their views on what should be considered important. In doing so, consumer facilitation was prioritized over the relationship-orientated concerns of the business. This is compatible with what is expected within a systems perspective, namely that anticipated role behaviour would not only be identified, but that order of preference/importance would also be indicated. It was indicated that business ideals and customer needs are often irreconcilable in practice.

The ideal salesperson from customer's point of view Salespeople apparently have no doubt about the importance of their assistance during consumers' evaluation of merchandise.

Role in a task orientated context Only tasks directly relevant to consumer facilitation were mentioned. These confirmed characteristics mentioned during interviews, namely objectivity, knowledge and experience. Due to the nature of this specific task (from the customer's point of view) no administrative functions were mentioned.

Role in a relationship-orientated context Criteria that were stipulated in this exercise confirmed those identified during the interviews namely that good relationships with customers were vital and that a positive attitude, trust and respect were required. No additional information or contradictory statements came to the fore.

The ideal salesperson from colleague's point of view A salesperson's role as colleague seems to be neglected by management and should be regarded a major contributor to stress and role conflict in the work place that negatively impacts on performance and job satisfaction.

Role in a task orientated context

Overall, the same parameters as those from an employer's point of view were included, namely the administrative role, sales and the supportive role (consumer facilitation).
In addition, the supportive role of colleagues was included. As this did not reflect what was actually happening in practice, it might reflect the need for conflict resolution. The image of a salesperson as influenced by personal appearance and dress code was again stressed as important.

Role in a relationship orientated context A salesperson's relationship with customers and colleagues were mentioned. The fact that no reference to management was made probably confirms the problematic superior-subordinate roles that were complained about during interviews unless managers were perceived as colleagues in this exercise? Patience, commitment and a positive attitude were identified as crucial characteristics.

\section{DISCUSSION OF FINDINGS}

\section{The role of the salesperson as employee}

When participants were prompted to describe their roles during daily routine in the retail environment, the task related responsibilities were spontaneously discussed first. Participants generally agreed on the responsibilities that are associated with this role. These included organizational/administrative tasks; acting as product specialist as well as sales. These were later confirmed through the projective technique. Conversely, ambiguity in terms of the role as product specialist became evident, mostly because management seldom supported or initiated further training of salespeople, although they were expected to be experts in their field. The remark that "if you leave the floor for training or whatever, you loose sales and commission" explains their dilemma. Long working hours and resultant time pressure apparently complicate the matter and contribute to work related stress. Despite their complaints about management's evident disregard of their contribution in the work place and their personal needs, participants perceived it as a form of trust when they had to represent management during interaction with customers for the best part of the day. Statements such as "we fight our own battles" illustrate their confusion. The need for a formal structure that allows a ranking system to acknowledge those who excel in their work was recommended.

\section{The role of the salesperson as consumer facilitator}

This role encouraged lively discussions and comprehensive descriptions inclusive of task related and relationship-orientated statements. Although the salesperson's role as consumer facilitator appears to be considered very important and even the preferred role, a discussion of the various roles and the collective role of the salesperson as illustrated in Figure 1, perhaps best describes the dilemma a salesperson is confronted with on a daily basis. The salesperson seems to juggle the comprehensive role of a salesperson in an attempt to cope with what is expected in various capacities: as employee: (to increase sales); as individual (who often depends on commission to survive 
financially) and acting as a knowledgeable, honest, objective consumer facilitator where consumers have to be treated as friends to clinch a deal. Although a salesperson's empathy towards consumers was apparent and was confirmed in the projective technique, it was also evident that this had to be neglected in a subtle way when conflicting situations occurred. No wonder then that "nobody trusts us". This is consistent with the findings of Beatty et al (1996) that a salesperson's customer orientation is determined by management's customer orientation.

\section{The role of the salesperson as colleague}

In contrast to the other categories, participants had to be encouraged to discuss this aspect. In the projective techniques, criteria for this category were abbreviated and reflected a wish list when compared to interview responses. The task related role was conflicting in terms of supporting one another but standing the chance of loosing a sale and commission to a colleague. This role seemed to be less prominent and more problematic for some. The need to better understand the internal quality of an organization, which includes employee-employee relations and the consequential impact on employee-customer relationships, has been suggested before (Beatty et al, 1996).

\section{The role of the salesperson as an individual}

Again, participants had to be encouraged to elaborate. The diminished focus on this role is probably confirmed by a salesperson's perception of being a subordinate, not having the opportunity to be promoted through a "ranking system", not being trusted by all consumers, not being supported in terms of personal needs. A salesperson, does however seem to enjoy the job (referring to customer service, getting to know people, helping others). The role of consumer facilitator thus seems to compensate for the personal dimension that contained several, rather serious negative statements. Almost as if being the victim of the situation, the salesperson reduces this role.

\section{The collective role of a salesperson}

The collective role of a salesperson in the working environment seems complex and stressful. Despite not necessarily having a formal job description, individual participants agreed on the various dimensions of a salesperson's role. Consumer facilitation seemed to be regarded very important and the most enjoyable role that also contributes to salespeople's personal worth. From this, we can unfortunately not assume optimal customer assistance. It seems as if salespeople often feel more obliged towards their role as employee that require of them to increase sales because that also contributes to better incomes through increased commissions.

Within the systems perspective, the juggling of responsibilities illustrates the principle of equifinality, suggesting that alternative routes are followed to cope with the collective role. Instead of emphasis on consumer support that is preferred and emphasized when discussed separately, sales is focused on for the better of the business and higher commissions. The latter two dimensions are thus promoted and in so doing, consumer support is overshadowed and diminished. Commission based remuneration is also blamed for poor relations among colleagues (another role that is neglected) because competition for sales prevent them from supporting one another. This contributes to tension in the working environment that is exaggerated by long working hours and lack of acknowledgement by supervisors.

\section{CONSEQUENCES FOR INFORMED CONSUMER DECISION-MAKING}

The collective role of a salesperson seems problematic in terms of the discrepancy in the emphasis that is placed on the individual role perceptions by salespeople and their managers (as indicated through the projective technique where participants had to react on behalf of their managers based on their experience in the work place) and the consequent role conflict that complicates sales behaviour. This may indicate that consumers are on the loosing end, especially where commission based remuneration becomes relevant. This apparently provokes competitiveness among colleagues and often causes a salesperson to refrain from exposing truthful product information to consumers to prevent him/her from loosing a sale that could contribute to his performance record and the commission that is earned. This should be further investigated as a matter of concern - especially regarding durable products such as household technology where the average consumer should be able to depend on salespeople to guide them towards informed, responsible purchase decisions. It further seems as if management in retail will have to refocus in terms of how problems - of which commission based remuneration seems the worst - can be amended. A study by Buttle and Burton (2002) found customer service, which is vital for the survival of businesses, to be dependent on customers' perception of value. Any idea that a salesperson cannot be trusted will thus be exceptionally harmful to business. Word of mount is considered as major contributor to the image and the successes of businesses (Blodgett et al, 1995). In this context, further investigation into the ability of salespeople to integrate their role related responsibilities so that the role as consumer facilitator could be reinstated as a priority, is suggested.

\section{REFERENCES}

BABBIE, E \& MOUTON, J. 2001. The practice of social research. South African Ed. Oxford. University Press.

BEATTY, SE, MAYER, M, COLEMAN, JE, REYNOLDS, KE \& LEE, J. 1996. Customer salesassociate retail relationships. Journal of Retailing 72 (3):223-247.

BETTENCOURT, LA \& BROWN, SW. 1997. Contact employees: relationships among workplace fairness, job satisfaction and prosocial service behaviors. Jour- 
nal of Retailing 73(1):39-61.

BLODGETT, JG, WAKEFIELD, KL \& BARNES, JH. 1995. The effects of customer service on consumer complaining behavior. Journal of Services Marketing 9 (4):31-42.

BUTTLE, F \& BURTON, J. 2002. Does service failure influence customer loyalty? Journal of Consumer Behaviour 1(3):217-227.

CAMPBELL, MC \& KIRMANI, A. 2000. Consumers' use of persuasion knowledge. The effects of accessibility and cognitive capacity on perceptions of an influence agent. Journal of Consumer Research 27 (June):69-83.

CHERNEV, A. 2003. When more is less and less is more: the role of ideal point availability and assortment in consumer choice. Journal of Consumer Research 30(September): 170-183.

CHURCHILL, GA JR, FORD, NM \& WALKER, OC JR. 1990. Sales force management. Planning, implementation and control. $3^{\text {rd }}$ Ed. Homewood. Irwin.

CLOPTON, SW, STODDARD, JE \& CLAY, JW. 2001. Salesperson characteristics affecting customer complaint responses. Journal of Consumer Behaviour 1 (2):124-139

CUFF, EC \& PAYNE, GCF. 1981. Perspectives in sociology. London. George Allen.

DAVIES, FM. 2001. Critical factors in consumer supermarket shopping behaviour. A neutral network approach. Journal of Consumer Behaviour 1(1):35-49.

DONOGHUE, S. 2000. Projective techniques in consumer research. Journal of Family Ecology and Consumer Sciences (28):47-53.

DU PLESSIS, PJ, ROUSSEAU, GG \& BLEM, NH. 1999: Buyer behaviour. A multi cultural approach. $2^{\text {nd }}$ Ed. Halfway House. International Thompson.

EVANS, KR, KLEINE, RE III, LANDRY, TD \& CROSBY, LA. 2000. How first impressions of a customer impact effectiveness in an initial sales encounter. Journal of Academy and Marketing Science 28 (40):512-526.

GOFF, BG, BOLES, JS, BELLENGER, DN \& STOJACK, C. 1997. The influence of salesperson selling behaviors on customer satisfaction with products. Journal of Retailing 73(2):171-183.

GREWAL, D \& SHARMA, A. 1991. The effect of sales force behavior on customer satisfaction. An interactive framework. Journal of Personal Selling and Sales Management 11(Summer):13-23.

HALAMBOS, M. 1983. Sociology, themes \& perspectives. London. University Tutorial Press.

HAMMERSLEY, M \& ATKINSON, P. 1995. Ethnography. $2^{\text {nd }} E d$. London. Routledge.

HUFFMAN, C \& KAHN, B. 1998. Variety for sale. Mass customization or mass confusion. Journal of Retailing 74(4):491-513.

JACOBS, RS, HYMAN, MR \& MCQUITTY, S. 2000. Exchange specific self disclosure, social self disclosure and personal selling. Journal of Marketing Theory and Practice (Winter):8-62.

JARVIS, C. Role analysis. Business open learning archive. [WWW.document-27-08-2002] http://www.brunel.ac.uk/ bustcfj/bola/competence/role.html JOBBER, D. 1998. Principles and practice of marketing. $2^{\text {nd }}$ Ed. London. McGraw-Hill.

KOTLER, P. 1994. Marketing management. Analysis, planning, implementation and control. $8^{\text {th }}$ Ed. Englewood Cliffs, New Jersey. A Simon \& Schuster.
KVALE, S. 1996. Interviews. An introduction to qualitative research interviewing. Thousand Oaks, California. Sage.

MARINO, P. 2001. The seven secrets of selling. [WWW document - 19-07-2002] http://www.furninfo.com/absolutenm/templates/Article _-

Retailing. asp?articleid=974\&zoneid $=4$

MEGGINSON, L.C. 1977. Personnel and human resources administration. $3^{\text {rd }}$ Ed. Homewood, Illinois. Richard D Irwin.

MORRIS, N. 2002. Moral marketing. Can ethics and profits co - exist? Future Business. Marketing, Media \& Business in S.A. (April):28-31.

MOUTON, J. 1996. Understanding social research. Pretoria. Van Schaiks.

NAYLOR, G \& FRANK, KE. 2000. The impact of retail sales force responsiveness on consumers' perceptions of value. Journal of Services Marketing 14 (4/5):310-343.

PERREAULT, WD \& LEIGH, LE. 1989. Reliability of nominal data based on qualitative judgments. Journal of Marketing Research 26(May):135-148.

PETTIJOHN, CE, PETTIJOHN, LS \& TAYLOR, AJ. 2000: An exploratory analysis of salesperson perceptions of the criteria used in performance appraisals, job satisfaction and organizational commitment. Journal of Personal Selling \& Sales Management 20(2):7780.

PLANK, RE \& REID, DA. 1994. The mediating role of sales behaviors: an alternative perspective of sales performance and effectiveness. The Journal of Personal Selling and Sales Management 14(Summer):4356

REYNOLDS, KE \& BEATTY, SE. 1999. A relationship customer typology. Journal of Retailing 75(4):509-523. SAMSON, HE \& LITTLE, WG. 1993. Retail merchandising. Consumer goods and services. $11^{\text {th }}$ Ed. Cincinnati. South - Western.

SHARMA, A \& LEVY, M. 1995. Categorization of customers by retail sales people. Journal of Retailing 71 (1):71-81.

SPEARS, MC \& GREGOIRE, MB. 2003. Food service organizations: A managerial and systems approach. $5^{\text {th }}$ Ed. Upper Saddle River. New Jersey. Pearson.

TYSON, S \& YORK, A. 1996. Human resource management. $3^{\text {rd }}$ Ed. Oxford Made Simple Books. London. Butterworth-Heinemann.

WALLENDORF, M \& BELK, RW. 1989. Assessing trustworthiness in naturalistic consumer research. Interpretive Consumer Research: 69-84. Vancouver. Washington State University.

WEINSTEIN, B. 2001. Fifteen tips for mastering the art of selling. [Www Document - 24-05-2002] http:// www.itworld.com/career/4205/ITW010503salesspecial4/pfindex.html

WETZELS, M, DE RUYTER, K \& BLOEMER, J. 2000. Antecedents and consequences of role stress of sales persons. Journal of Retailing and Consumer Services 7:65-75.

WHITCHURCH, GC \& CONSTANTINE, LL. 1993. In BOSS, PG, DOHERTY,WJ, LA ROSSA, R, SCHUMM, WR \& STEINMETZ, SK. 1993. Sourcebook od family theories and methods. New York. Plenum.

WINSTED, KF, 1997. The service experience in two cultures: A behavioral perspective. Journal of Retailing 73(3):337-360. 